\title{
Malgorzata Cieciura
}

Państwowa Wyższa Szkoła Zawodowa w Koninie

e-mail:m.cieciura@wp.pl

\section{Hanna Czaja-Cieszyńska}

Uniwersytet Szczeciński

e-mail: hanna.czaja@wzieu.pl

\section{RACHUNKOWOŚĆ W ŚWIETLE ZALOŻEŃ PSYCHOLOGII NA TEMAT NATURY CZLOWIEKA}

ACCOUNTING IN THE LIGHT OF PSYCHOLOGY ASSUMPTIONS ON HUMAN NATURE

DOI: $10.15611 / \mathrm{pn} .2018 .513 .06$

JEL Classification: M41, G41

Streszczenie: Rachunkowości jako systemowi informacyjnemu przypisuje się dziś miano języka biznesu, który ma być czytelny na skalę globalną. Jednocześnie sygnalizuje się, że rachunkowość w obecnym kształcie boryka się z wieloma dylematami. W tym kontekście autorki artykułu podjęły dyskusję na temat wykorzystania dorobku dynamicznie rozwijającej się w ostatnich latach psychologii do analizy zagadnień typowych dla systemu rachunkowości. Za cel artykułu przyjęto konfrontację założeń głównych nurtów współczesnej psychologii na temat natury człowieka z realizacją naczelnej zasady systemu rachunkowości finansowej, jaką jest zasada wiernego i rzetelnego obrazu jednostki gospodarczej. W artykule posłużono się krytyczną analizą literatury oraz metodą dedukcji.

Słowa kluczowe: rachunkowość, psychologia, człowiek, informacja.

Summary: Accounting as an information system is nowadays called the language of business, which has to be readable on a global scale. At the same time, it is signaled that accounting in the current form is struggling with many dilemmas. In this context, the authors of the article have discussed the use of the output of dynamically developing psychology in recent years to analyze issues typical of the accounting system. The aim of the article is to confront the main assumptions of contemporary psychology about the nature of human with the implementation of the guiding principle of the financial accounting system which is the principle of true and fair view of the business unit. In the article, a critical analysis of literature and the method of deduction were used.

Keywords: accounting, psychology, human, information. 


\section{Wstęp}

Nie ulega wątpliwości, że współczesna rachunkowość jest narażona na ciągłe przeobrażenia. Postrzegana jako zintegrowany system pozyskiwania, agregowania, ujmowania i prezentowania wyrażonej wartościowo informacji ekonomicznej, musi działać w turbulentnym otoczeniu, które charakteryzuje permanentna zmiana. Informacji ekonomicznej przypisuje się dziś miano podstawowego zasobu, który w połączeniu z wiedzą daje możliwości uzyskania przewagi konkurencyjnej i realizowania strategii wzrostu wartości przedsiębiorstwa. Na rachunkowości, jako systemie, ciąży więc duża odpowiedzialność i trudne zadanie zachowania zasady wiernego i rzetelnego obrazu jednostki gospodarczej. Wiadomo już, że odwołanie się rachunkowości wyłącznie do perspektywy wartościowej i ilościowej nie wyczerpuje złożoności procesów zachodzących w jednostce gospodarczej. Wymiar wartościowy i ilościowy jest niewystarczający do pokazania pełnego zakresu informacji, które odbiorca sprawozdania finansowego mógłby wykorzystać w procesie podejmowania decyzji ekonomicznych. Pojawia się tu przede wszystkim problem wiarygodnego i rzetelnego odwzorowania za pomocą wartości szeroko rozumianych zasobów niematerialnych. Dlatego też w literaturze przedmiotu coraz częściej sygnalizuje się konieczność poszerzenia wartościowego wymiaru rachunkowości, już nie tylko o cechy jakościowe informacji ekonomicznych, ale o nowe perspektywy postrzegania zadań stawianych przed rachunkowością. Jedną z takich perspektyw jest w ostatnich latach perspektywa psychologiczna.

Podjęte w niniejszym artykule rozważania są próbą konfrontacji systemu rachunkowości z wyodrębnianymi obecnie przez psychologię jej głównymi podejściami. Sednem dociekań psychologii jest badanie przyczyn zachowań ludzkich. Autorki, konfrontując w swoich rozważaniach system rachunkowości z założeniami psychologii, koncentrują się na tych nurtach, które skupiają uwagę na motywach i schematach działania człowieka jako wyodrębnionego bytu, czyli jako jednostki charakteryzującej się określonymi procesami myślowymi i jako istoty społecznej, która prezentuje pewne schematy zachowań wynikające z bycia członkiem społeczności.

Celem artykułu jest uwydatnienie znaczenia ustaleń głównych nurtów współczesnej psychologii dla analizy zagadnień rachunkowych. Przewodnia myśl opracowania skupia się wokół tezy, że świadomość psychologicznych schematów funkcjonowania człowieka jako jednostki i jako członka społeczności może być istotna dla realizowania celu i zachowania zasad systemu rachunkowości finansowej oraz że naturalne procesy determinujące i określające zachowanie ludzi mogą stanowić pewnego rodzaju inspiracje do analizy systemu rachunkowości finansowej jako generatora informacji. W artykule zastosowano krytyczną analizę literatury i metodę dedukcji. 


\section{Psychologiczne podejścia do natury czlowieka a rachunkowość}

Istotnym kontekstem współczesnej rachunkowości, nie tylko jako nauki, ale również (a może przede wszystkim) jako dziedziny praktycznej, jest globalizacja, złożoność i specyfika procesów gospodarczych, które system rachunkowości powinien odwzorować w wymiarze wartościowym. W ścisłej korelacji z powyższym pozostaje to, że obserwuje się obecnie przeniesienie środka ciężkości w tworzeniu wartości przedsiębiorstwa $\mathrm{z}$ aktywów materialnych na bardzo trudno mierzalne i identyfikowalne zasoby niematerialne. Wypracowane przez wieki teorie i zasady rachunkowości skupiają się w głównej mierze na metodach pomiaru, zakładając osiągnięcie wiarygodnych i rzetelnych szacunków w tak trudnych obecnie i obarczonych dużą dozą subiektywizmu obszarach, jak utrata wartości aktywów czy zastosowanie wartości godziwej. Tymczasem, zarówno w praktyce, jak i na gruncie fundamentalnych zasad rachunkowości, pojawia się wiele pytań, na które niełatwo znaleźć odpowiedź. Być może brakującym elementem, który mógłby wzmocnić czy też uzupełnić analizę dylematów współczesnej rachunkowości, powinno być systemowe uwzględnienie psychologicznych czynników w obszarze rachunkowości. Truizmem jest stwierdzenie, że za tworzenie zasad, szukanie niestandardowych rozwiązań, sporządzanie sprawozdań finansowych itp. odpowiedzialny jest człowiek. Paradoksalnie jednak (pomijając kwestię etyki, o której w ostatnich latach mówi się dużo) człowiek jako byt psychologiczny jest uwzględniany w systemie rachunkowości wciąż w stopniu marginalnym. Kołodziej i Maruszewska [2016, s. 37] stwierdzają, że „do prawidłowego wykonywania usług rachunkowości wymagana jest nie tylko znajomość teorii i prawa o rachunkowości, ale przede wszystkim konieczna jest umiejętność jego aplikowania w skomplikowanej rzeczywistości gospodarczej współczesnych przedsiębiorstw". Wydaje się zatem, że aspekt psychologiczny rachunkowości nabiera szczególnego znaczenia w konfrontacji z jej praktycznym wymiarem.

Na przestrzeni ostatnich stu lat psychologia jako nauka przeprowadziła szereg badań i eksperymentów, które pozwoliły zgromadzić wiedzę na temat poznania natury człowieka w aspektach: poznawczym, emocjonalnym, motywacyjnym, osobowościowym i społecznym. Wypracowano wiele koncepcji wyjaśniających mechanizmy funkcjonowania ludzi, które mają swoje odzwierciedlenie w kilku promowanych obecnie kierunkach psychologii. Podkreśla się przy tym, że w zasadzie żadne z podejść samodzielnie nie wyczerpuje wyjaśniania złożoności procesów kierujących postępowaniem i zachowaniem człowieka, ale każde z nich ,przyczynia się do lepszego rozumienia całości ludzkich doświadczeń" [Zimbardo, Gerrig 2012, s. 13]. W tabeli 1 przedstawiono syntetyczną charakterystykę głównych kierunków współczesnej psychologii.

Odwołując się do badań prowadzonych w różnych obszarach wiedzy, z całą pewnością należy stwierdzić, że z doświadczenia psychologii korzysta obecnie wiele dyscyplin naukowych. W obliczu podważenia paradygmatu homo oeconomicus z doświadczenia psychologii czerpie się w głównej mierze po to, aby zrozumieć „po- 
Tabela 1. Charakterystyka współczesnych podejść w psychologii w odniesieniu do natury człowieka

\begin{tabular}{|c|c|c|}
\hline Lp. & $\begin{array}{c}\text { Podejście } \\
\text { w psychologii }\end{array}$ & Promowane podejście do natury człowieka \\
\hline 1 & biologiczne & $\begin{array}{l}\text { Przyczyn zachowania ludzkiego szuka się w działaniu genów, mózgu, } \\
\text { układu nerwowego i układu wydzielania wewnętrznego (hormonalnym). } \\
\text { Według tego podejścia, zachowania człowieka interpretuje się jako wynik } \\
\text { procesów chemicznych i elektrycznych, które zachodzą wewnątrz komórek } \\
\text { nerwowych i pomiędzy nimi. Natura człowieka jest określana jako bierna, } \\
\text { mechanistyczna. Za determinanty zachowania uważa się zatem dziedziczność } \\
\text { i procesy biochemiczne. Główny temat badań w ramach tego podejścia to } \\
\text { procesy zachodzące w mózgu i układzie nerwowym, natomiast badania } \\
\text { podstawowe oscylują wokół biochemicznych podstaw zachowania i procesów } \\
\text { umysłowych }\end{array}$ \\
\hline 2 & psychodynamiczne & $\begin{array}{l}\text { Zachowanie jest motywowane przez siły wewnętrzne (instynkt). Przyczyną } \\
\text { ludzkich działań są wrodzone instynkty, biologiczne popędy i usiłowania } \\
\text { zmierzające do rozwiązania konfliktów między potrzebami osobistymi } \\
\text { a wymaganiami społeczeństwa. Energię do działania generują stany } \\
\text { deprywacji, konflikty i pobudzenie fizjologiczne. Badania podstawowe } \\
\text { dotyczą zachowania jako zewnętrznego wyrazu nieświadomych motywów }\end{array}$ \\
\hline 3 & behawiorystyczne & $\begin{array}{l}\text { W ramach podejścia behawiorystycznego bada się, jak poszczególne bodźce } \\
\text { środowiskowe kontrolują określone rodzaje zachowania. Natura człowieka } \\
\text { w tym podejściu jest określana jako „reagująca na bodźce”, ,dająca się } \\
\text { modyfikować”. Badania podstawowe w kierunku behawiorystycznym } \\
\text { obejmują przyczyny bodźcowe i konsekwencje zachowań }\end{array}$ \\
\hline 4 & poznawcze & $\begin{array}{l}\text { Przedmiotem badania podejścia poznawczego są procesy myślowe } \\
\text { (umysłowe) związane z gromadzeniem wiedzy, takie jak spostrzeganie, } \\
\text { pamięć, posługiwanie się językiem, rozwiązywanie problemów, } \\
\text { podejmowanie decyzji. Psychologowie poznawczy uważają, że myśli są } \\
\text { zarówno skutkami, jak i przyczynami działań zewnętrznych. Z poznawczego } \\
\text { punktu widzenia otaczająca rzeczywistość jest taka, jaką człowiek postrzega } \\
\text { w subiektywnej rzeczywistości wewnętrznego świata myśli i wyobraźni. } \\
\text { Podejście poznawcze jest uważane za dominujące w dzisiejszej psychologii }\end{array}$ \\
\hline 5 & humanistyczne & $\begin{array}{l}\text { W psychologii zgodnej z kierunkiem humanistycznym prawidłowości czy } \\
\text { wzorów zachowania szuka się w ludzkich biografiach. Przy czym zakłada } \\
\text { się, że głównym zadaniem człowieka jest dążenie do pozytywnego rozwoju. } \\
\text { Kierunek humanistyczny promuje holistyczne podejście do źródeł natury } \\
\text { człowieka polegające na połączeniu wiedzy o psychice, ciele i zachowaniu } \\
\text { jednostki ze znajomością sił społecznych i kulturowych }\end{array}$ \\
\hline 6 & ewolucjonistyczne & $\begin{array}{l}\text { W podejściu ewolucjonistycznym zakłada się, że zdolności umysłowe } \\
\text { człowieka kształtują się w procesie ewolucji, służąc konkretnym celom } \\
\text { przystosowawczym (podobnie jak umiejętności fizyczne). Podstawową } \\
\text { różnicą podejścia ewolucjonistycznego i innych podejść w psychologii jest } \\
\text { przyjęcie odmiennej (bardzo długiej) perspektywy czasowej. Stąd też badania } \\
\text { podstawowe w ramach tego podejścia koncentrują się na mechanizmach } \\
\text { psychicznych w kategoriach funkcji przystosowawczych ukształtowanych } \\
\text { w drodze ewolucji }\end{array}$ \\
\hline
\end{tabular}

Źródło: opracowanie własne na podstawie [Zimbardo, Gerrig 2012, s. 13-17]. 
zaracjonalne" mechanizmy zachowania i funkcjonowania człowieka jako uczestnika rynku, członka organizacji, konsumenta, inwestora, klienta itp. Dlatego też interdyscyplinarność badań naukowych ze szczególnym udziałem psychologii jest dziś zjawiskiem co najmniej częstym. W ramach owej interdyscyplinarności analizuje się związki psychologii z ekonomią, zarządzaniem, finansami, prawem, a także rachunkowością.

Odnosząc przedstawione w tabeli 1 współczesne podejścia psychologii do natury ludzkiej z innymi dyscyplinami naukowymi, trzeba podkreślić, że obecnie dominujące znaczenie mają dwa podejścia - behawiorystyczne i poznawcze, przy czym oba podejścia, odnosząc się do mechanizmów działania natury człowieka jako jednostki, są dodatkowo konfrontowane (uzupełniane) z doświadczeniami i ustaleniami psychologii społecznej ${ }^{1}$. Zestawianie badań poszczególnych nurtów psychologii w odniesieniu do natury jednostki z ustaleniami psychologii społecznej wydaje się być absolutnie konieczne dla holistycznego spojrzenia na naturę ludzką i motywy działań człowieka. W praktyce gospodarczej bowiem człowiek jest elementem pewnej zbiorowości i relacje, jakie zachodzą między członkami tej zbiorowości, nie pozostają bez wpływu na postępowanie jednostki, a co za tym idzie, na funkcjonowanie całego systemu.

\section{Rachunkowość w kontekście wybranych obszarów psychologii}

Przyjmując założenie podporządkowania działań systemu rachunkowości finansowej, w dzisiejszym złożonym i szybko zmieniającym się otoczeniu gospodarczym, realizacji jej naczelnej funkcji (generowanie użytecznej informacji) w kontekście zachowania jej naczelnej zasady (true and fair view), trzeba stwierdzić z całą stanowczością, że człowiek jako realizator, strażnik i kontroler założeń systemu rachunkowości finansowej znalazł się w dość trudnej sytuacji. Na nim to bowiem spoczywa obowiązek wiernego, wiarygodnego i rzetelnego odwzorowania w mierniku pieniężnym rzeczywistości gospodarczej danego podmiotu. Wartościowe odzwierciedlenie informacji w systemie rachunkowości staje się problematyczne z kilku względów. Po pierwsze, problematyczne jest przechodzenie od wycen bazujących na cenie nabycia czy koszcie wytworzenia do wycen opartych na wartości godziwej, czyli w dużej mierze na wartości szacunkowej, podatnej na subiektywizm i manipulacje. Po drugie, jednostki gospodarcze to obecnie wielopłaszczyznowe struktury posiadające różnorodne zasoby finansowe, rzeczowe i niematerialne, przy czym tym ostatnim, w obecnych czasach, przypisuje się pierwszorzędne znaczenie, a które są trudno mierzalne i niejednokrotnie trudne do zidentyfikowania. Po trzecie, otoczenie gospodarcze, jako odbiorca informacji pochodzących z systemu rachunkowości, staje się coraz bardziej wymagające. Dyskutuje się zatem na temat kształtu i zakresu

${ }^{1}$ Psychologia społeczna jest definiowana jako „naukowe badania sposobu, w jaki rzeczywista bądź wyobrażona obecność innych ludzi wywiera wpływ na ludzkie myślenie, odczuwanie i zachowania” [Aronson, Akert, Wilson 2012, s. 35]. 
informacji wykazywanych w sprawozdaniu finansowym oraz jej wymiaru (konfrontując ze sobą wymiar finansowy i niefinansowy). Należy zgodzić się ze stwierdzeniem Maruszewskiej [2014, s. 111], że „tworzona w rachunkowości informacja zależna jest od przyjętych nieweryfikowalnych (lub w najlepszym razie trudno weryfikowalnych) założeń, których źródła wynikają z subiektywnych ocen rzeczywistości ekonomicznej, w jakiej działa podmiot gospodarczy”. Wydaje się zatem niepodważalne, że znaczenie decyzji i osądów, które pozostają w gestii człowieka jako kreatora rzeczywistości gospodarczej podmiotu, wymaga obecnie dużego zaangażowania procesów poznawczych. Ponadto zachowanie w praktyce gospodarczej naczelnej zasady rachunkowości i realizacja jej głównej funkcji wymaga od ludzi zaangażowanych $\mathrm{w}$ ten system posiadania interdyscyplinarnej wiedzy (prawo bilansowe, prawo podatkowe, prawo gospodarcze, zasady etyczne). Uprawnia to do przyjęcia założenia, że tworzenie i funkcjonowanie systemu rachunkowości finansowej powinno być rozpatrywane nie tylko na gruncie dyscyplin z dziedziny nauk ekonomicznych czy prawnych, ale również na gruncie dyscyplin z dziedziny nauk społecznych, takich jak psychologia czy socjologia.

Nie ulega wątpliwości, że w kontekście łączenia psychologii z innymi dziedzinami nauki w ostatnich latach w literaturze przedmiotu i w praktyce gospodarczej podkreśla się najczęściej znaczenie psychologii behawioralnej. O związkach behawioryzmu z różnymi dziedzinami i dyscyplinami naukowymi napisano niewątpliwie najwięcej. Również w odniesieniu do rachunkowości powstał nurt badań określany mianem rachunkowości behawioralnej. Oczywiście nie należy bagatelizować tego nurtu, ale trzeba podkreślić, że odnosi się on w głównej mierze do zarządczych aspektów rachunkowości i wciąż w niewielkim stopniu uwzględnia procesy myślowe (kognitywne), ograniczając się raczej do analizy reakcji człowieka na bodźce zewnętrzne. Należy bowiem mieć świadomość, że w psychologii behawioralnej podłoża kształtującego zachowanie upatruje się w procesach uczenia się i ciągłej interakcji organizmu ze środowiskiem [Przytuła 2008, s. 37], co z pewnością nie wyczerpuje wyjaśniania złożoności natury ludzkiej. Dla behawiorystów najistotniejsze są zjawiska, które da się zaobserwować. Przedmiotem badań psychologicznych są tu dostrzegalne zachowania ludzi, a nie uzyskiwane na drodze introspekcji wewnętrzne motywy ich działania. Dlatego też połączenie rachunkowości z behawioryzmem jako jednym z nurtów psychologii spotyka się obecnie z polemiką [Nowak 2015, s. 287-296; Nowak 2016, s. 150-160]. Wydaje się, że ludzkie działania w obszarze sytemu, jakim jest rachunkowość, należy rozpatrywać nie tylko pod kątem przystosowania się człowieka do środowiska (otoczenia gospodarczego), ale również pod kątem procesów psychicznych, czyli procesów związanych z funkcjonowaniem ludzkiego umysłu. Pojawia się zatem uzasadnione pytanie, czy w przypadku rachunkowości powinno się mówić o rachunkowości behawioralnej, czy raczej o psychologii w rachunkowości, co dawałoby możliwość holistycznego spojrzenia na psychologiczne aspekty rachunkowości w odniesieniu zarówno do teorii, jak i praktyki rachunkowości.

Analizując związek psychologii z rachunkowością na poziomie systemowym, należy podkreślić, że rachunkowość, poprzez swój swoisty produkt, jakim jest wie- 
loelementowe sprawozdanie finansowe, uzyskuje dziś miano ,języka biznesu”. Można zatem przyjąć założenie, że przy wykorzystaniu rachunkowości zostaje uskuteczniony proces komunikacji między nadawcą komunikatu, czyli przedsiębiorstwem, które przekazuje (nadaje) różnego rodzaju informacje w sprawozdaniu finansowym, a odbiorcą komunikatu, czyli szeroko rozumianym otoczeniem jednostki. Korzystając z ustaleń psychologii, można przełożyć ten swoisty proces komunikacji jednostki z otoczeniem gospodarczym na proces komunikacji międzyludzkiej i podjąć próbę dokonania analizy elementów składowych obu procesów.

Z psychologicznego punktu widzenia proces komunikacji między ludźmi, czyli tzw. komunikacja interpersonalna, powinien przebiegać według ujętego w pewne ramy schematu, zgodnie z którym nadawca, przy użyciu odpowiedniego kodu (najczęściej są to słowa), przesyła odbiorcy informację, wykorzystując różne kanały przekazu. Odbiorca nadanej informacji dekoduje ją, odczytuje i daje nadawcy informację zwrotną. Gwarantem sukcesu w komunikacji między ludźmi jest posługiwanie się kodem, który jest znany obu stronom. Dodatkowo trzeba mieć świadomość, że w procesie komunikacji interpersonalnej ludzie posługują się komunikatami zarówno werbalnymi (słownymi), jak i niewerbalnymi (przekazywanymi poprzez mimikę twarzy, postawę ciała, wygląd fizyczny, dotyk itp.). Werbalizowanie przekazu niewątpliwie daje możliwość uzewnętrznienia dużej liczby informacji. Nie zmienia to jednak faktu, że słowa nie wyczerpują treści, którą nadawca chce przesłać odbiorcy. Zgodnie z ustaleniami psychologii procentowy udział przekazu werbalnego w komunikacji między ludźmi (włączając w to brzmienie głosu) szacuje się na ok. $35 \%$, reszta - czyli ok. $65 \%$, to przekaz niewerbalny ${ }^{2}$. Okazuje się zatem, że przekaz niewerbalny jest niezwykle ważny. Niezwykle ważne jest również to, żeby zachować spójność między przekazem słownym i pozasłownym. W przypadku braku spójności odbiorcy komunikatu są skłonni przychylać się do przekazu niewerbalnego, ignorując tym samym treść wypowiedzi.

Odnosząc proces komunikacji przedsiębiorstwa z otoczeniem za pomocą informacji wykazywanych w sprawozdaniu finansowym do komunikacji międzyludzkiej, można przyjąć założenie, że odpowiednikiem przekazu werbalnego między ludźmi są wykazywane w sprawozdaniu finansowym dane finansowe (wyrażone w mierniku pieniężnym). Znając znaczenie przekazu werbalnego i niewerbalnego w procesie porozumiewania się między ludźmi, można się zatem zastanawiać, czy (podobnie jak w komunikacji interpersonalnej) nie przeceniamy jako twórcy i odbiorcy sprawozdań finansowych znaczenia informacji wyrażanych za pomocą wartości. Posługując się przywołaną analogią, atrybuty przekazu niewerbalnego (jak się okazuje, bardzo ważnego w komunikacji międzyludzkiej) należałoby przypisać danym niefinansowym. Proponując porównanie komunikacji przedsiębiorstw z otoczeniem gospodarczym poprzez rachunkowość do komunikacji interpersonalnej, autorki wyra-

\footnotetext{
2 Wydaje się, że przekaz niewerbalny jest tak bardzo istotny, ponieważ mówi o stanach emocjonalnych, oczekiwaniach, intencjach. Ponadto przekaz niewerbalny jest często nadawany i odbierany na poziomie nieświadomym, co powoduje, że trudniej nim manipulować.
} 
żają pogląd, że być może wyzwaniem rachunkowości XXI wieku (bardziej istotnym, niż by się mogło wydawać) jest nie tyle i nie tylko poszukiwanie wiarygodnych i rzetelnych metod pomiaru, ile również poszukiwanie innych obszarów, przestrzeni oraz form tworzenia i przekazywania informacji otoczeniu gospodarczemu.

Analizując z kolei związek psychologii z rachunkowością w jej praktycznym wymiarze, w którym zadania stawiane przed poszczególnymi uczestnikami systemu rachunkowości wymagają pracy pod presją czasu, podejmowania decyzji w kwestii przyjmowania niestandardowych rozwiązań, brania odpowiedzialności za przyjęte rozwiązania itp., należy przyjrzeć się ustaleniom nurtu psychologii poznawczej. Niezwykle istotne dla realizacji praktycznego wymiaru rachunkowości wydają się być ustalenia psychologii poznawczej dotyczące sposobów przetwarzania przez człowieka informacji. Okazuje się bowiem, że w naturze człowieka leży przetwarzanie informacji zarówno w sposób analityczny (systematycznie, powolnie i świadomie), jak i heurystyczny (wybiórczo, szybko, automatycznie i często nieświadomie), przy czym ten ostatni może prowadzić do powstawania tzw. błędów poznawczych [Kahneman $2012]^{3}$. Heurystyczne przetwarzanie informacji jest charakterystyczne dla działania pod presją czasu. Co ciekawe, posługiwanie się w praktyce gospodarczej uproszczonymi schematami myślenia i wnioskowania dotyczy zarówno laików w danej dziedzinie, jak i profesjonalistów dysponujących ogromną wiedzą i doświadczeniem [Falkowski, Zaleśkiewicz 2012, s. 17-18]. Bardzo ważną konkluzją badań prowadzonych w obszarze sposobów przetwarzania informacji przez ludzi jest przyjęcie założenia, że reguły racjonalnego wyboru są nieustannie łamane przez uproszczone, intuicyjne schematy myślenia (co nie oznacza, że decyzje podejmowane intuicyjnie są gorsze, wręcz przeciwnie, niejednokrotnie są to decyzje trafione i właściwe). Trzeba zatem mieć na względzie, że decydenci w procesie podejmowania decyzji są obarczeni szeregiem, najczęściej nieuświadomionych, ograniczeń, które wynikają z przyzwyczajeń, stereotypów, schematów i braku dostępności do informacji.

\section{Zakończenie}

Niewątpliwe jest to, że prowadzone obecnie badania zarówno w obszarze nauk ekonomicznych (w tym rachunkowości), jak i psychologii przekładają się na praktykę życia gospodarczego. Za spektakularne należy uznać to, że badania prowadzone na styku psychologii i ekonomii zostały nagrodzone dwukrotnie na przestrzeni ostatnich 15 lat prestiżową Nagrodą Banku Szwecji im. Alfreda Nobla ${ }^{4}$. Przy czym trzeba

${ }^{3}$ W 1974 r. A. Tversky i D. Kahneman opublikowali w tygodniu „Science” artykuł na temat heurystyk i błędów poznawczych. Opisali w nim skróty i uproszczenia, którymi posługują się ludzie w myśleniu intuicyjnym, i wyjaśnili naturę około dwudziestu błędów poznawczych będących przejawem omówionych w artykule heurystyk.

${ }^{4}$ Chodzi o dorobek Daniela Kahnemana i Amosa Tversky'ego oraz Richarda Thalera. Daniel Kahneman za stosowanie narzędzi z psychologii w badaniach ekonomicznych, ze szczególnym uwzględnieniem opracowanej wspólnie z Amosem Tverskym teorii perspektywy, otrzymał w $2002 \mathrm{r}$. Nagrodę Nobla w dziedzinie ekonomii. Richard Thaler został nagrodzony za badania dotyczące psychologii podejmowania decyzji ekonomicznych Nagrodą Nobla w 2017 r. 
podkreślić, że nagrodzone badania dotyczyły w dużej mierze analizy procesów myślowych zachodzących w ludzkim umyśle. Tak więc należy uznać, że znaczenie psychologii w dziedzinie nauk ekonomicznych jest duże i ma swoje dość solidne osadzenie teoretyczne. Nie zmienia to jednak faktu, że dyskusje o związkach psychologii z informacyjnym systemem rachunkowości finansowej pozostają wciąż w sferze rozważań akademickich. Co prawda w literaturze przedmiotu w ostatnich kilkudziesięciu latach sygnalizuje się potrzebę uwzględnienia przez rachunkowość badań psychologii nad naturą ludzką, wydaje się jednak, że nie są to działania systemowe, które mogłyby doprowadzić do trwałych zmian. Można stwierdzić, że szczególnie w odniesieniu do informacyjnego systemu rachunkowości finansowej, która tworzy przecież bazę dla analizowania zagadnień w ramach rachunkowości zarządczej, analizy finansowej, budżetowania i wielu innych obszarów związanych z wykorzystaniem informacji ekonomicznej, teoria rachunkowości nie posiada holistycznych, spójnych rozwiązań w obszarze wykorzystania badań psychologii. A przecież, co starano się zasygnalizować w niniejszym artykule, analiza dylematów i słabości współczesnej rachunkowości w odniesieniu do badań psychologii mogłaby zyskać nowe obszary do zagospodarowania.

\section{Literatura}

Aronson E., Akert R.M., Wilson D., 2012, Psychologia spoteczna. Serce i umyst, Zysk i S-ka, Poznań. Falkowski A., Zaleśkiewicz T., 2012, Teoria i praktyka psychologii poznawczej, [w:] A. Falkowski, T. Zaleśkiewicz, Psychologia poznawcza w praktyce. Ekonomia. Biznes. Polityka, Wydawnictwo Naukowe PWN, Warszawa.

Kahneman D., 2012, Pułapki myślenia. O myśleniu wolnym i szybkim, Wydawnictwo Media Rodzina, Poznań.

Kołodziej S., Maruszewska E.W., 2016, Skłonność do unikania i uchylania się od opodatkowania $w$ świetle teorii moralnego rozwoju Kohlberga - zagadnienia etyczne w praktyce rachunkowości, Zeszyty Teoretyczne Rachunkowości, t. 86, SKwP, Warszawa.

Maruszewska E.W., 2014, Współczesna rachunkowość a etyka zawodowa w polskiej literaturze z zakresu rachunkowości finansowej, Zeszyty Naukowe Uniwersytetu Ekonomicznego w Katowicach. Studia Ekonomiczne nr 164, Wydawnictwo Uniwersytetu Ekonomicznego w Katowicach, Katowice.

Nowak M., 2015, Pomiędzy rachunkowościa a psami Pawłowa, czyli krytyka pojęcia „rachunkowość behawioralna", Prace Naukowe Uniwersytetu Ekonomicznego we Wrocławiu, nr 389.

Nowak M., 2016, Semantyka terminu ,rachunkowość behawioralna”. Problemy znaczeniowe, Zeszyty Naukowe Uniwersytetu Ekonomicznego w Katowicach, nr 300.

Przytuła S., 2008, Psychologia zarządzania. Wybrane zagadnienia, Wydawnictwo Uniwersytetu Ekonomicznego we Wrocławiu, Wrocław.

Zimbardo P.G., Gerrig R.J., 2012, Psychologia i życie, Wydawnictwo Naukowe PWN, Warszawa. 